\title{
Students’ Academic Engagement in Small Group
}

\author{
Lasito \\ Universitas Negeri Jakarta, Jakarta, Indonesia \\ lasito@unj.ac.id
}

\begin{abstract}
This study looked at students' academic engagements when they worked in small groups to prepare speech drafts in an EFL classroom. In particular, the study examined what students were focusing and kind of thinking processes occurred during deliberations. The analysis is based on deliberation segments from students' transcripts to see the focus of discussion and twodimensional Revised Bloom Taxonomy (Anderson \&Krathwohl, 2001) to analyse the thinking processes students demonstrated. Results showed that during deliberations, students were more focused on content of the speech $(\mathbf{7 3 , 8 3 \%})$ rather than on the language $(26,17 \%)$. In terms of thinking processes, results from knowledge dimension axes showed that two most knowledge elicited during deliberations were factual knowledge $(\mathbf{8 2 , 8 1 \%})$ and conceptual knowledge $(17,19 \%)$ with no discussion on procedural knowledge and metacognitive knowledge. On another axis, cognitive process dimension, results showed that students cognitive processing fit in remembering $(\mathbf{7 4 , 6 1 \% )}$, understanding $(23,44 \%)$, and analysing $(1,95 \%)$ information. There were no incidents of applying, evaluating, and creating.
\end{abstract}

Keywords: small group, academic engagement, knowledge dimension, cognitive process dimension

\section{INTRODUCTION}

In a foreign language context where classrooms are usually filled with lots of students, assigning students to work in small groups becomes an ideal option. Research has shown that small groups are supportive for language learning in that they enable learners to negotiate and modify language output 1 . (Eckerth, 2009; Foster \&Ohta, 2005; Fujii\& Mackey, 2009; Izumi \& Bigelow, 2000; Mackey, et.al, 2007; Mayo \& Pica,2. 2000; Muranoi, 2000; Nakahama, et.al, 2001). When students are negotiating, they will engage in clarification requests and comprehension checks. These processes are considered to be able to enhance second language acquisition (Ellis \& He, 1999). Working in small groups also helps learners to solve linguistic problem they encountered during interaction and is evident in their test results (Donato, 1994; Swain \&Lapkin, 1998).

Working in small groups also enables learners to develop their critical thinking. Through small groups, learners are engaged in exploratory talks which enable them to evaluate people's arguments (Mercer, 1996; 2000). Howe (2009) also believes that learners' ability to cope with differences in groups will increase their cognitive development. Studies addressing the small groups and critical thinking development, however, have only limited their investigation on the relationship between working in small groups and critical thinking development (Fung \& Howe, 2012), how small groups allow learners to develop learning strategies in thinking development (Ku \& Ho, 2010), and how different kinds of questions would enable learners to respond them critically (Almeida, 2010; Godfrey, 2001; Seker\&Komur, 2008).

By far, small groups have been considered as a strategy in carrying out a task or learning activities in a broader sense. Most often, small groups are embodied in a preparation activity (task planning) before subsequent individual or group presentations. Studies on this nature (e.g. Ortega 1999,2005; Sanagarun 2005; Wendel 1997) have shown that students benefit task planning for subsequent presentation. However, those studies are individual in nature. A study addressing small group for task planning is Truong and Storch (2007). They modified the task planning into small group discussion and investigated how such a planning impact performance. The study found that during planning, students engaged more on deliberation of meaning (content of a presentation) over the form (language). They also identified that most of the ideas presented in the presentation (performance stage) were derived from ideas in planning activities.

While scholars believe that small group activities (pre-task planning) are beneficial for second language acquisition and closely related with critical thinking development, there is no such a study integrating those foci in one single task. This study is built on that concern, and posed to seek answers for the following research questions:

What was students' focus when they deliberated in small groups?

What kinds of thinking processes students demonstrated when they worked in small groups?

\section{METHODS \\ 2.1 Participant}

This study was conducted in English Department at one of the universities in Jakarta, Indonesia. It involves 35 students (12 males and 13 females) in their second year (semester 3) studying public speaking course. For research purposes, students are grouped into 14 groups; seven groups working in pairs and another seven groups working in triads.

\subsection{Task}

Students worked in their groups to prepare a draft of informative speech. The speech was aimed at promoting Indonesia tourism destinations. Firstly, students brainstormed the speech draft in their groups for 30 minutes. At this time, students were allowed to make use of materials such as brochures, leaflets, or tourism websites. After that, students wrote the speech script in a piece of paper in another 30 
minutes. Their deliberation during brainstorm activities and script writing were audiotaped.

\subsection{Data}

Data was taken from the audio-taped of students' deliberation in brainstorm activities and script writing. They are then transcribed for further analysis of learning episodes. Students' speech scripts were also analyzed for a cross evidence between brainstorm activities and the speech scripts.

\subsection{Data Analysis}

Data analysis is based on two measures, they are students' focus of deliberation and thinking processes occurred when students work in small groups.

\section{a. Focus of Deliberation}

To determine students' focus of deliberation, firstly I listened and transcribed the audio recordings. Then I carefully examined segments of interactions where students deliberated the task. The focus of deliberation is seen from deliberation about the language and deliberation about the content. Deliberation about the language is any instances when students deliberated about the language (language use, grammar, spelling, etc). Below is an example of students' deliberation about the language.

\section{Excerpt 1}

20 Shella: em... I'd like to tell you, I would like to tell or inform?

21 Dilla: Kalo ini gak formal pake tell aja. [if it is informal better use 'tell' ]

22 Shella: Jangan to tell deh, inform aja. [oh... not to tell, to inform I think]

23 Dilla: inform kan lebih formal, kalau lo mau friendly, mendingan pake tell. ['to inform' is more formal, if you want to be more friendly you should use 'tell']

24 Shella: Pake inform aja deh. [I think inform we will use 'inform']

25 Dilla: I would like to inform you about Taman Matahari aja ya? [I would like to inform you about Taman Matahari, like that?]

\section{Shella: Yaudah [right]}

From the excerpt we know that Shella is going to write an introduction of the speech by stating the purpose of the speech. However, she was not sure to use 'tell' or 'inform'. Dilla then suggested to use 'tell' if the context is informal. There was a small argument whether they should use 'tell' or 'inform'. Finally, they came into a conclusion that their speech would be written in a more formal way, therefore, they decided to use 'inform' in their speech.

Meanwhile, deliberation about content is any instances when students talked about the content of their speech (outline of the speech, detail information of the speech, etc). below is an example of deliberation about the content.

\section{Excerpt 2}

Widya: Oh gitu, jadi introduction-nya kaya gimana? [ Oh I see, so how's the introduction like?]

15 Dinar: Good morning everybody, I'm from..... (blah blah blah...)

Anton: Iya, abis itu kasih penjelasan dikit [yes, after that we give a small information]

17 Widya: Penjelasan apaan Ton? [What information Anton?]

18 Anton: Kita jelasin dikit tentangWakatobi island-nya terus habis itu kita

jelasin dive resort-nya. [we give information about Wakatobi Island, after that we explain about the diving resort.]

Excerpt 2 illustrates how this group discussed about the structure of the speech they were going to present. After a small introduction, Anton suggested to have a general information about Wakatobi island, then detail elaboration of the diving resort as the main attraction.

\section{b. Thinking Processes}

To understand the thinking processes occurred during deliberations, I used reference of revised Bloom Taxonomy model (Anderson \&Krathwohl, 2001). Therefore, analysis will be based on two axes of the taxonomy; the knowledge dimension and the cognitive process dimension. 
TABLE 1. THINKING PROCESSES

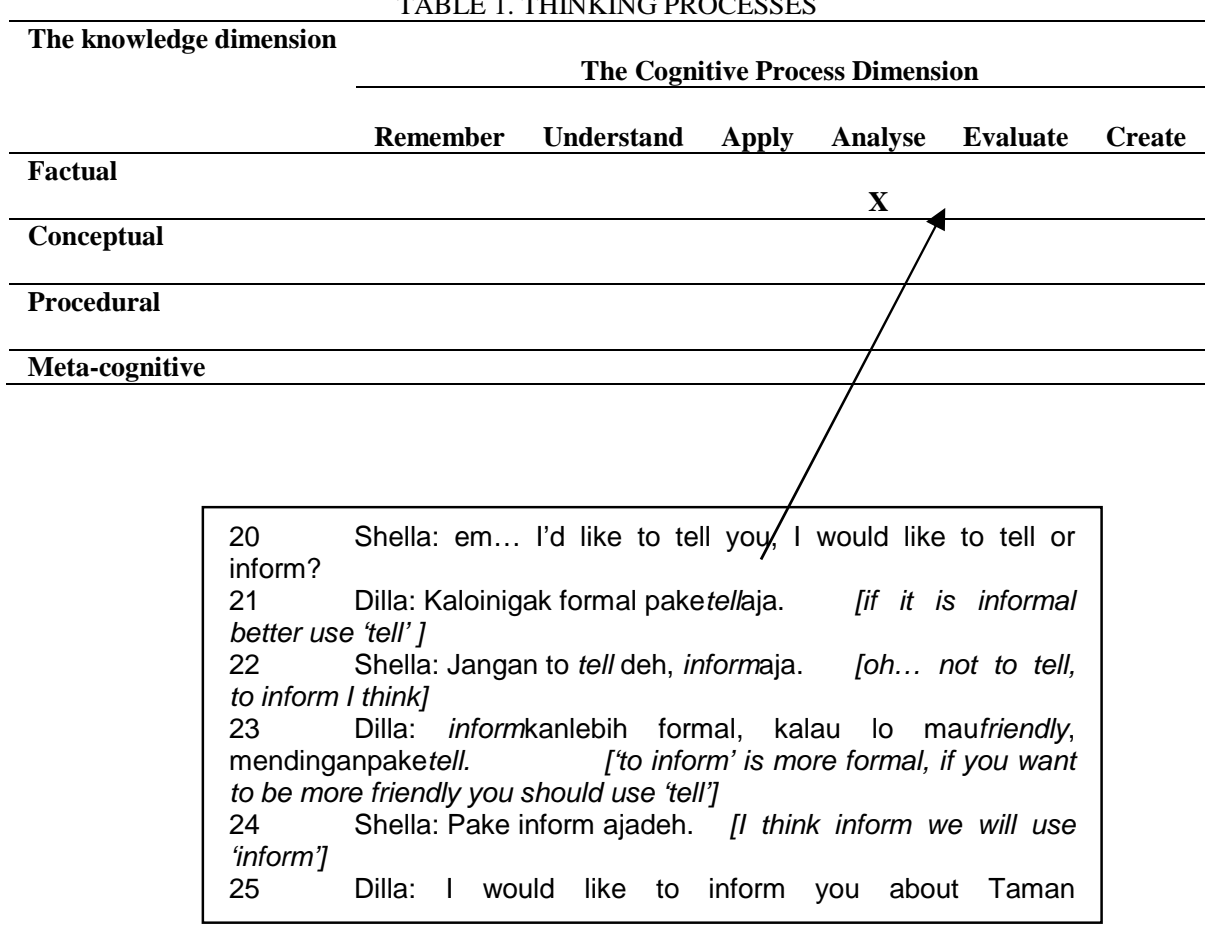

Table 1 shows the thinking processes seen from two corresponding axes; knowledge dimension and cognitive process dimension. From the transcript plotting, we know that in terms of knowledge, students were deliberating factual knowledge (knowledge of word, definition or terminology). This is evident when they were arguing whether to use the word 'tell' or 'inform'. In terms of cognitive processes, students demonstrated analysis function in which they differentiate the word 'tell' and 'inform' with reference of formal or informal use and to implement (use) it in the corresponding context.

\section{RESULTS AND DISCUSSION}

This study is aimed at investigating what happened when students were deliberating in a pre-task planning. First, it looked at what students focused during deliberation then it examined further what thinking processes occured during deliberation.

What was students' focus when they deliberated in small groups?

The study revealed that deliberation in small groups has led to students' active engagement in the task. During task processing, students were deliberating more on content $(73.83 \%)$ than on language $(26.17 \%)$. When deliberating on content, students were likely to talk about the speech outline and what information in each part would likely be. While deliberation on language was minimal, it only discussed vocabulary to elaborate the content.

\section{Chart 1. Focus of Deliberation}

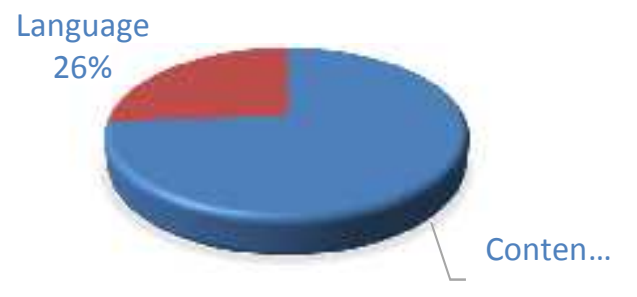

The domination of discussion on content over the language was associated with the task given. The task requires students to compose a draft of speech for the purpose of speech presentation. In such condition, people will usually focus on the delivery of ideas or content/meaning they are going to present and until later, they will work on the language/form they use (Ortega 1999; 2005; Sangarun 2005; Wendel 1997). A similar finding was also present in Truong and Storch(2007) study. They found that during pre-task planning, students intensely rehearsed on the ideas for their speech and little discussion on language. The present study also found that discussion on language was mostly on vocabulary, and there was no evidence of discussion on grammar (Truong\&Storch, 2007).

\section{What kinds of thinking processes students demonstrate when they worked in small groups?}

Analysis in cognitve processing showed that most of the knowledge recalled in the deliberation was factual knowledge $(82,81 \%)$ with a small proportion of deliberation about conceptual knowledge $(17,19 \%)$. However, there were 
no incidents of deliberating on procedural knowledge and metacognitive knowledge.

\section{Chart 2. Knowledge Dimension}

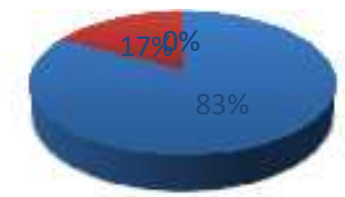

$$
\begin{aligned}
& \text { - Factual Knowledge (82.81\%) } \\
& \text { - Conceptual Knowledge (17.19\%) } \\
& \text { - Procedural Knowledge (0\%) } \\
& \text { — Metacognitive Knowledge (0\%) }
\end{aligned}
$$

The factual knowledge rehearsed during deliberation were associated with detail information about the tourist object such as locations, facilities, costs, and any other related information. It also appeared when students worked with meaning making through terms and vocabulary. The conceptual knowledge is associated with students' understanding of the concept of speech draft such as introduction and attention getter, content part, closing part, and how certain information would fit each part.

On another axes, cognitive processes rehearsed was mostly remembering $(74,61 \%)$, with some degree of understanding $(23,44 \%)$, and very few of analyzing $(1,95 \%)$. There were, however, no incidents of mental rehearsing on

\begin{tabular}{|c|c|}
\hline Remembering (74.61\%) & U Understanding (23.44\%) \\
\hline Applying (0\%) & Analyzing (1.95\%) \\
\hline Evaluating (0\%) & Creating (0\%) \\
\hline
\end{tabular}
applying, evaluating and creating.

\section{Chart 3. Cognitive Process Dimension}

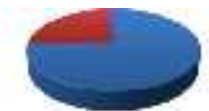

Remembering state was reflected from activities of stating and locating factual information students know about the attraction. Understanding state was shown through classifying information to the corresponding part in speech outline. During deliberation, it was also evident that students translated words or phrases from brochures, leaflets or web. This activity was considered as students' effort to build understanding on the attraction. It should be noted that this study was built on language skill base and it only focused on one learning episode. It is these, therefore, that applying and creating states laid on the task itself.

\section{CONCLUSION}

This study looked into how students approach a task through collaboration in small groups. In particular, it examined what students were focusing during deliberation and what thinking processes were demonstrated in approaching the task. Results showed that students were deliberating about content over the language. It was the task that made students tended to do so. In a communicative task where the outcome is oral presentation, meaning delivery is paramount. Deliberation on language was closely related to vocabulary for meaning making purpose. In terms of thinking processing, students rehearsed more on factual knowledge and conceptual knowledge. The factual knowledge is associated with factual information about the tourist attractions and vocabulary elicitations and meanings. The conceptual knowledge is to do with students understanding on speech and elements comprising it. Therefore, reflection of this knowledge is coded when students decided which information belong to which part. Students' knowledge processing dominated by remembering and understanding the concept with a little portion of analysis. The strength of this study lies in extending the nature of pre-task planning to the thinking processes identification. While not all knowledge dimensions and cognitive process dimensions are identifiable in this study, it should be seen with cautious that it might be the task affected this. Therefore, further investigation on different tasks and in one complete cycles of teaching and learning activities shall be worth for future studies.

\section{REFERENCES}

Almeida, P.A. (2010). Questioning pattern, questioning profiles, and teaching strategies in secondary education.The international journal of learning 17 (1), 587- 600 .

Anderson, et.al.(2001). A taxonomy for learning, teaching.and assessing: a revision of bloom's taxonomy of educational objectives. US.Longman.21-91.

Donato, R (1994) Collective scaffolding in second language learning. In: Lantolf $\mathrm{J}$ and Appel G(eds) Vygotskian approaches to second language research. Norwood, NJ: Ablex, pp.33-56.

Eckerth, J (2009) Negotiated interaction in the 12 classroom. Language Teaching 42(1): 109-130

Ellis R. and He X (1999) The roles of modified input and output in the incidental acquisition of word meanings. Studies in Second Language Acquisition 21(2): 285-301

Foster P and Ohta AS (2005) Negotiation for meaning and peer assistance in second languageclassrooms. Applied Linguistics 26(3): 402-430.

Fujii A and Mackey A (2009) Interactional feedback in learner-learner interactions in a task-based EFL classroom.International Review of Applied Linguistics (IRAL) 47(3-4): 267-301.

Fung, D. and Howe, C. (2012). Liberal studies in hongkong: a new perspective of critical thinking through groupwork. Thinking Skills and Creativity (7), 101-111 
Godfrey, K.A. (2001). Teachers's questioning technique, students responses and critical thinking. Unpublished Master Thesis,ERIC.

Howe, C. (2009). Collaborative groupwork in middle childhood. Human Development, 52, 215-239.

Izumi S and Bigelow M (2000) Does output promote noticing and second language acquisition? TESOL Quarterly 34(2): 239-278.

Ku. K.Y.L, \&Ho, I.T,.(2010). Metacognitive strategies that enhance critical thinking.Metacognitive Learning (5), 251-267.

Mackey A, Kanganas AP and Oliver R (2007) Task familiarity and interactional feedback in child ESL classroom. TESOL Quarterly 41 (2): 285-312.

Mayo MP and Pica T (2000) Interaction among proficient learners: are input, feedback and output needs addressed in foreign language context. StudiaLinguistica 54(2): 272-279.

Mercer, N. (1996). The quality of talk in children's collaborative activity in the classroom.Learning and Instruction, 6, 359-377.

Mercer, N. (2000). Words and minds: How we use language to think together. London: Routledge.

Muranoi, H. (2000) Focus on form through interaction enhancement: integrating formal instruction into a communicative task in EFL classrooms. Language Learning 50(4): 617- 673.

Nakahama Y, Tyler A and van Lier L (2001) Negotiation of meaning in conversational and information gap activities: a comparative discourse analysis. TESOL Quarterly 35 (3): $377-405$

Ortega, L. (1999).Planning and focus on form in L2 oral performance, Studies in Second

Language Acquisition, 21:109-48.

Ortega, L. (2005). 'What Do Learners Plan? Learner-driven Attention to Form during Pre-task

Planning', in R. Ellis (ed.). Planning and Task Performance in a Second Language (Amsterdam/Philadelphia: John Benjamins).

Sanagarun, J. (2005). 'The Effects of Focusing on Meaning and Form in Strategic Planning', in R. Ellis (ed.). Planning and Task Performance in a Second Language (Amsterdam/Philadelphia: John Benjamins).

Seker, H. \&Komur, S. (2008). The relationships between critical thinking skills and in-class questioning behaviours of english language teacher students. European Journal of Teacher Education, 31(4). 389-402.

Swain M and Lapkin S (1998) Interaction and second language learning : Two adolescent French immersion students working together. The Modern Language Journal, 82(3): 320 - 337.

Truong AT and Storch N (2007) Investigating group planning in preparation for oral presentations in an efl class in Vietnam. RELC Journal 38 (1): 104-124.

Wendel, J.N. (1997). 'Planning and Second Language Narrative Production' (Unpublished

doctoral dissertation. Temple University, Japan). 